\title{
A Comparative Analysis of Funding Schemes for Public Infrastructure Spending in Quebec
}

\author{
By \\ Dorothée Boccanfuso, Marcelin Joanis, Patrick Richard et Luc Savard

\begin{abstract}
The economic literature has been investigating the positive relation between public infrastructure spending and the productivity of the private sector since Munnell (1992). We have introduced this relationship into a recursive dynamic computable general equilibrium model of the Quebec economy to investigate various funding schemes to scale up infrastructure spending in the province. We draw our assumptions from Estache et al. (2010) combined with sectoral elasticity parameters. We conduct a comparative analysis where the funding comes from debt alone, and debt with sales tax, income tax and business tax. Our main finding is that the income tax seems to produce the most positive effects and the businesses tax the most negative effects, though differences are small.
\end{abstract}

Key Words: CGE model, infrastructure, productivity

JEL codes: D58, H54, H63, O47 


\section{Introduction}

For a number of years, economists have pointed out the existence of a positive relation between investments in public infrastructure and the productivity of the private sectors of the economy (Barro, 1991). Since Aschauer (1989) and Munnell (1992) stressed the important role of the public sector in funding infrastructure to stimulate economic development, a vast literature has dealt with this issue. Theoretical models and empirical studies have attempted to shed some light on this relationship. Some authors believe that a decline in productivity would be induced by slow expansion of the public infrastructure investment in the past (Bergman and Suan 1996; Binder and Smith 1997; Hakfoort 1996). Others argue that significant infrastructure scaling-up will result in inflation and loss of competiveness (Gupta et al 2006). There is also an important body of literature on public investment dealing with eviction of private investment.

In Quebec, a massive plan for infrastructure renewal was implemented by the provincial government in 2007 (Secrétariat du Conseil du trésor 2007). The collapse of the Concorde boulevard overpass in Laval in September 2006 was the main trigger for the Quebec government's decision to accelerate public infrastructure repairs in the province. In 2007, the Plan québécois d’infrastructures (PQI) was announced. The January 2009 economic statement illustrates higher public infrastructure spending than the trend in the past ten years (see Figure 1). According to the Quebec government, when we include the investments of the federal government in Quebec, of municipalities, and of HydroQuébec, public investments weighed in at 5.9\% of GDP in 2009 (ministère des Finances, 2009), a peak over the past 25 years. 
Figure 1: Evolution of investments made by the Quebec government (in billions of dollars)

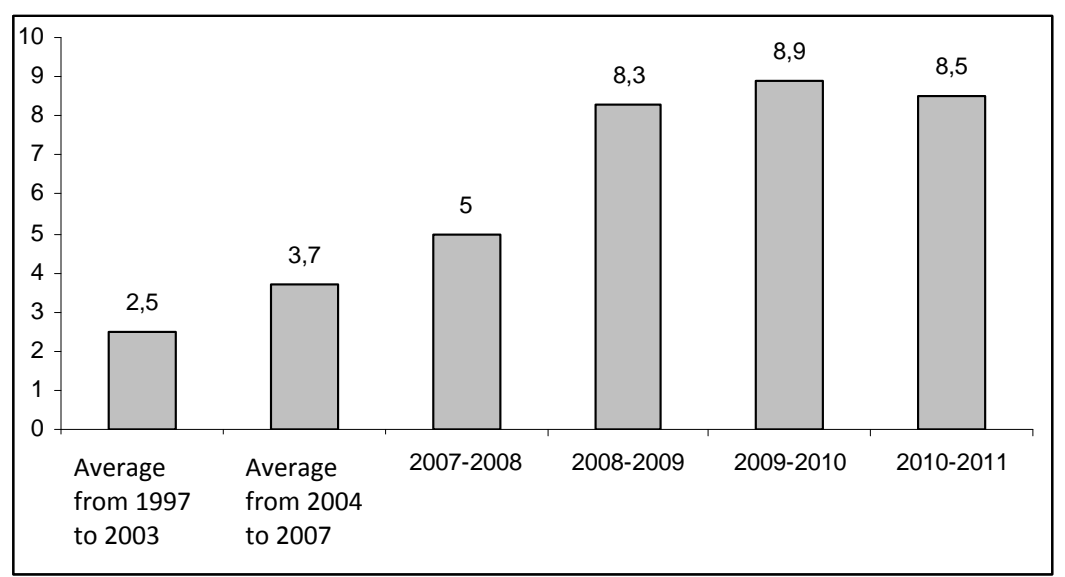

Source: Economic statement - Explanatory document, January 2009, Minitry of Finances of Québec, page 26.

For Quebec, these infrastructure expenditures were also justified by an important maintenance deficit in the public capital stock. According to the Treasury Board of Canada Secretariat-TBS (2007), public infrastructures in Quebec are ageing and the accumulated maintenance deficit is estimated at \$27 billion. Indeed, most infrastructures in Quebec were built between 1960 and 1980. Large budgets are now required to maintain a quality comparable to that of OECD countries. According to Gagnon et al. (2008), the average age of Quebec infrastructures reached a peak of 18.6 years in 2000, then declined slightly to 17.2 years in 2007 (see Figure 2). Quebec nonetheless possesses infrastructures older than the average in Canadian provinces (17.2 years vs. 16.3 years).

The five-year plan involving \$30 billion covering the 2007-2012 period has been increased to $\$ 41.8$ billion and extended to 2013 (see Figure 3). The objectives of these investments are to curb maintenance deficits and to answer new needs. 
Figure 2: Average age of public infrastructures in the provinces

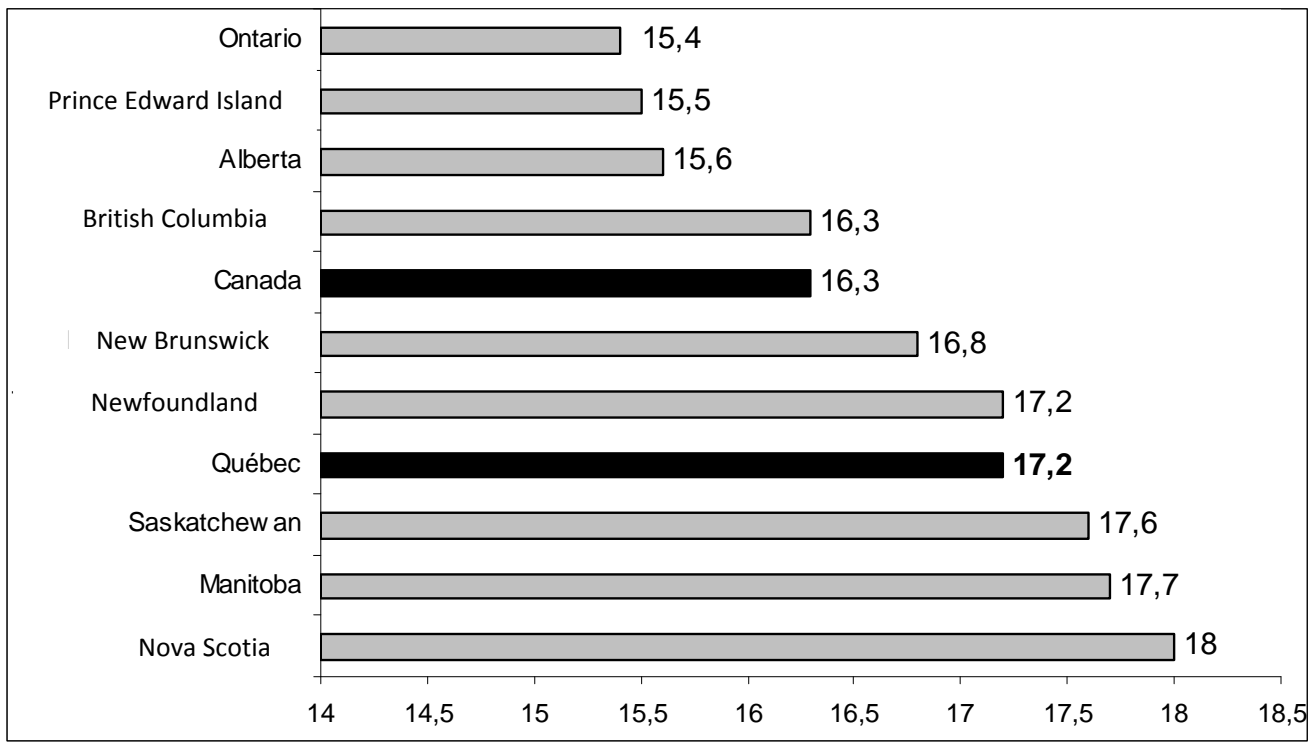

Source: Gagnon et al (2008), page 8.

Roughly 80 percent of the sum is devoted to maintaining assets already in place and the balance will go towards the construction of new infrastructures (SCT, 2007).

Figure 3: Investments of the Quebec government by sector (in billions \$ and in \%)

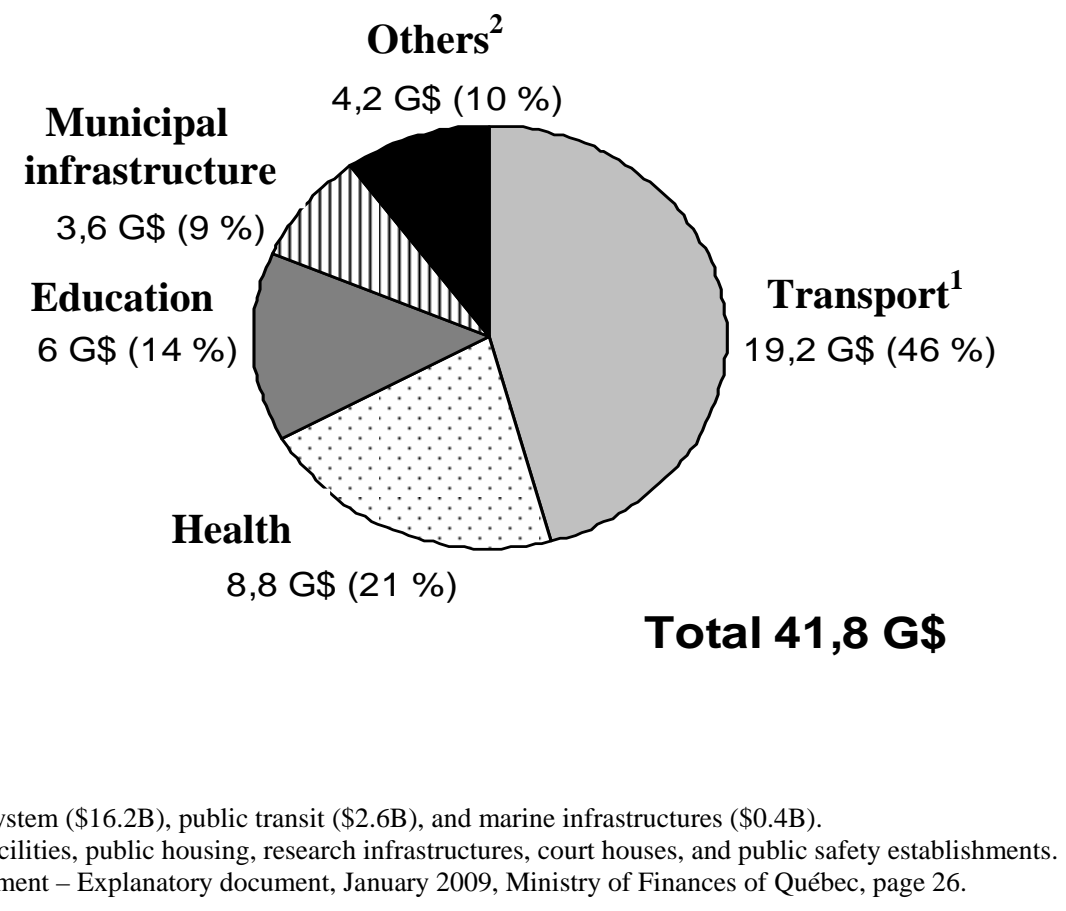

(1) Including the road system (\$16.2B), public transit (\$2.6B), and marine infrastructures (\$0.4B)

(2) Including cultural facilities, public housing, research infrastructures, court houses, and public safety establishments.

Source: Economic statement - Explanatory document, January 2009, Ministry of Finances of Québec, page 26. 
Most research on the positive relation between infrastructure spending and productivity has been undertaken in a partial equilibrium framework and with econometric models. Economists also use computable general equilibrium models (CGE) as an analytical tool to inform policy-makers on the economic impacts of policy reforms. In general, in CGE models, public expenditures and investments are not directly linked to productivity of private sector output. These only have an impact on the purchase of goods and services, and on employment in the public sector or the construction sector during the implementation stage. Over the past ten years or so, some authors have begun to introduce the externalities of public expenditures and investments into these models - see Savard and Adjovi (1998), Adam and Bevan (2006) and Estache et al (2010). The interest in using this methodology to analyse the scaling up of infrastructure lies in the tool's ability to simultaneously capture the external benefits of investments and most of their costs. The objective of this analysis is to perform a comparative analysis of various funding schemes to increase infrastructure spending in Quebec.

The analysis is conducted based on a 24 sector computable general equilibrium model of the Quebec economy. The text is divided into five sections. The first presents the theoretical issues linked to scaling up infrastructure. The second describes the methodological approach used for the analysis. Section three presents the simulations and results, and we close with some concluding remarks. 


\section{Theoretical stakes}

In this section, we address the economic stakes associated with an infrastructure increase in the economy. A vast body of literature has developed since Aschauer (1989) published his pioneer paper on the importance of public infrastructure spending to stimulate economic growth. We can refer to this relation as a positive externality of infrastructure spending on private productivity. ${ }^{1}$ For example, if a lane is added to a congested highway and this lane adds fluidity to traffic, a positive externality is generated through a gain in time for all users, a decrease in transport costs of merchandise, and improved quality of life. And yet, with the exception of the decrease in transport costs, the other benefits have no price determined by markets and it is partially because of these advantages that the additional lane is built.

Another important and controversial question is whether public infrastructure spending will decrease private investment (crowding-out effect) or will have a multiplier effect (complementarity). There are two schools of thought on the question and there is no consensus in empirical studies. The Keynesian approach stipulates that in a situation of underemployment an increase in public expenditures replaces a weak private investment and is legitimate (idea of complementarity). However, Keynesians do not advocate a deficit when the economy is near full employment. The Neoclassical school advances that there is a crowding-out of private investment. The rise in public expenditures, financed by taxation or debt, increases the demand for goods and services, decreases savings, increases interest rates, and thus decreases private investment (Ahmed and

\footnotetext{
${ }^{1}$ An externality is generated based on an action that positively or negatively affects an economic agent other than the one taking the action but that is not taken into account by any market (Varian, 1998).
} 
Miller, 1999). Moreover, if the infrastructures are financed by debt, part of the available savings can be shifted to the new issuing of government bonds, diverting the private investments towards this type of assets. Abdullatif (2006) asserts, for Japan between 1998 and 2006, that productive investments of the Japanese government financed by the issuing of bonds had a positive effect on the private sector. Based on an econometric model, Ahmed and Miller (1999) suggest that expenditures in a social assistance program reduce private investment for both developed and developing countries. On the other hand, infrastructure expenditures in transport and communication have a positive effect on private investment for their sample of developing countries and a non-significant effect for that of developed countries. They find that the establishment of a country's infrastructure network has diminishing marginal returns after a threshold is reached. The above-mentioned crowding-out theories were formulated at a time when national financial markets did not have the level of global integration they exhibit today. It is legitimate to question whether an increase in public expenditures affects the national interest rate in a context of integrated financial markets. Abdullatif (2006) maintains that public expenditures financed by loans do not affect the national interest rate because of the integration of world financial markets. Recent experiences in Iceland, Ireland and Greece would lead us to think that Abdullatif's (2006) claim would not be valid when debt to GDP ratios increase and get out of control. In the Quebec context, we use the findings of Abdullatif (2006) given the modest increases in debt to GDP ratio over the last few years (including the recession) as a working hypothesis ${ }^{2}$. The stylized facts support this hypothesis, as the Quebec investment program of $\$ 41.8$ billion over five

\footnotetext{
${ }^{2}$ It is important to add, as will be described below, that the working hypothesis will concern our exogenous interest rate, but that we will capture a crowding out effect given the budget constraints imposed by the CGE modeling framework.
} 
years is being carried out at the same time as Canadian interest rates decrease. ${ }^{3}$ However, this trend is in contradiction with what is defended by the proponents of the crowding out assumption. It should nevertheless be kept in mind that the situation might be different in a situation of full employment, which is not currently the case in Quebec and Canada. However, it is possible that in the medium or long term, the massive loans of various governments in the world contracted for infrastructures and the stabilization of their financial systems might lead to inflation and an increase in interest rates, thus harming private investment.

Taxation is another funding option for implementing an investment program. Ahmed and Miller (1999) arrive at the conclusion that financing through an increase in taxation is more harmful to private investment than loans. The crowding-out of private investment by public investment can also take place in another way. Indeed, a significant increase in the demand for public investment can monopolize a larger share of real supply and produce two negative impacts on private investment. First, an increase in demand in the short term without an adequate adjustment of supply in the same time horizon will increase prices, thus raising private investment costs. Second, if the government suddenly monopolizes a larger share of real supply, firms involved in public infrastructure projects may be obligated to turn down private contracts in the short term, thus decreasing private investment. These consequences on private investment are possible in the Quebec context. Firstly, the current infrastructure program is one of the largest in the history of the province. Are the involved sectors able to respond to the demand and continue to supply the demand for private investments without a price increase? The Commission de

\footnotetext{
${ }^{3}$ Interest rates have been at historically low levels for the last three years (see www.bankofcanada.ca).
} 
la construction du Québec (CCQ) planned to hire 14,000 new workers over four years ${ }^{4}$ to address the substantial increase in public investments. An increase in demand without an adequate adjustment of supply in the short term leads to a price increase. Secondly, in the context of a world economic crisis, the other North American jurisdictions also invest in their infrastructures, adding to the pressure on supply in this sector. The model will enable us to take into account most of the effects described, which cannot a priori be analyzed in a partial equilibrium framework. Using a CGE model that takes into account the various costs and externalities of public investments will allow us to see whether there is a crowding-out effect in the Quebec context.

In sum, though there is no consensus, the literature supports the fact that quality infrastructures have significant positive impacts on economic growth. Reserves are nevertheless expressed concerning their scope as well as the dynamic of the relation between public investment and private investment. We therefore analyze the establishment of the program with and without a positive relation between public infrastructure expenditures and economic growth.

\section{Methodology}

\subsection{CGE models and infrastructure}

Our objective is to use a CGE model of the Quebec with special features to capture public infrastructure externalities. Inter alia, the direct shock on the investment demand, externalities, the direct and indirect costs, and the impact on the sectors and households are taken into account in the model. A CGE model offers an analytical framework in

\footnotetext{
${ }^{4}$ Commission de la construction du Québec -CCQ (2008).
} 
which the economy is represented as a complete system of interdependent components. All economic agents, that is, households, firms, government and the external sectors are all related by transactions on the markets and the price system. The model captures the fact that an economic shock has subsequent effects on the entire economy, which is not the case in a partial equilibrium framework. Hence, the CGE model captures the feedback effects (indirect effects) of various policy simulations. For example, if the government increases its spending in public infrastructure, the CGE model enables us to take into account the direct effect of the expenditures on the economy, such as the increase in the GDP of the sectors involved, but also the fact that this stimulation of the GDP will increase government fiscal revenues and will modify the remuneration of production factors (Decaluwé et al., 2001). The CGE model provides a way to analyze many types of problems, but is primarily used to simulate changes in taxation in a broad sense. Changes to a direct or indirect tax, a tax credit, a customs tariff, or a transfer can be simulated using a CGE model, and their effects on the economy at large, as well as agents and sectors, can be analyzed (Decaluwé et al., 2001).

\subsection{The CGE model for Quebec}

The model implement for this paper draws from "EXTER” model of Decaluwé et al (2001) as a starting point. The specificities of the model are the following. The model is applied to a Social accounting matrix (SAM for 2006) built from the provincial inputoutput table produced by Statistics Canada. The model includes 24 production sectors. It also incorporates four agents, namely an aggregate household, one aggregate private firm, the government and the rest of the world. Production is determined through a 3-tier 
system: the total production of the branch $(X S)$ is made up of a fixed share between value-added $(V A)$ and intermediate consumptions $(C l)$. $V A$ is a combination of composite labour $(L D)$ and capital $(K D)$, which are related with a Cobb-Douglas function. Producers minimize their cost of producing $V A$ subject to the Cobb-Douglas function. We introduce an infrastructure externality parameter into this function, which we describe in more detail below. Optimal labour demand equations are derived from this process. We assume that capital is not mobile between sectors ${ }^{5}$. Intermediate consumptions are determined by a fixed share (Leontief) assumption. To capture the externalities of public expenditure and the growth effects, we developed a recursive dynamic version of the model. The multi-level production structure is composed of fixed coefficient intermediate inputs and these total intermediated inputs are combined to value added in fixed share (Leontief assumption). The value added is a combination of labour and capital that are related through a Cobb-Douglas production function. Capital is fixed between sectors and labour is mobile between sectors.

As in Savard (2010), the key assumptions to capture the impact of infrastructure spending concern their production externalities and the government budget constraint to fund these infrastructures ${ }^{6}$. This first equation (1.1) is the government budget constraint (equation 1.1) where government income $(Y g)$ is spent on public services or expenditures $(G)$ and on government savings $(S g)$, which will be used entirely for public investment.

$$
\text { 1. } S g=Y g-G
$$

\footnotetext{
${ }^{5}$ In the dynamics of the model, the new capital will go in priority to sectors exhibiting the highest returns. This mechanism captures some implicit mobility of capital between sectors

${ }^{6}$ We extend from Savard (2010) insofar as we have a recursive dynamic model that can include debt as a variable and funding tool for public infrastructure.
} 
We assume that public spending is exogenous and that public savings (the budget surplus) is endogenous. The public investment in infrastructure will be set exogenously and government will in part fund its objective with its current savings but will have access to a change in the stock of debt as a funding tool. We will identify this change in debt as a deficit.

$$
\text { 2. } I T G=S g+\text { deficit }
$$

The deficit will be funded by the three other agents in the model, namely households, private firms and the rest of the world ${ }^{7}$. In our simulation process we will modify the closure of this equation where the deficit will be held fixed and a tax rate will be used to balance this constraint ${ }^{8}$. An increase in debt will generate more interest payment for the government in subsequent periods but we will describe this below in the dynamic version of the model.

The externality equation (1.3) is the other important assumption, given its role in increasing the total productivity of factors in the value added equation (1.4). For this, we draw on the vast literature linking public infrastructure to private sector factor productivity, including Dumont and Mesplé-Somps (2000) in a CGE context, although our externality function does not include private investment. This function was also used in Estache et al. (2010) and Savard (2010). The function defining the externality is the following:

$$
\text { 3. } \theta_{t, i}=\left(\frac{K g_{t}}{K g_{t-1}}\right)^{\xi_{i}}
$$

\footnotetext{
${ }^{7}$ We calibrated the share of households at $30 \%$, firms at $50 \%$ and rest of the world at $20 \%$ based on discussions with debt managers of the Ministry of Finance of Quebec. This is an estimation on their part since they don't have the exact information on who hold Quebec government bonds.

${ }^{8}$ We will explain this in more detail when we describe our simulations.
} 
where $\theta_{i}$ is the externality or sectoral productivity effect, which is a function of the ratio of new stock of public capital $\left(K g_{t}\right)$ over public capital of the previous period $\left(\mathrm{Kg}_{t-1}\right)$ with a sector-specific elasticity $\left(\xi_{i}\right)^{9}$. The stock of public capital is determined by the following equation:

$$
\text { 4. } K g_{t}=K g_{t-1}\left(1+g_{k g}\right)^{t}\left(1-\delta_{g}\right)^{t}+I T G_{t-1}\left(1-\delta_{g}\right)^{t-1}
$$

where the level of stock of public capital of the previous period $\left(\mathrm{Kg}_{t-1}\right)$ grows at a rate of $g_{k g}$ which corresponds to the level of investment required to maintain the capital stock. The $\delta_{\mathrm{kg}}$ is the depreciation rate of public capital and $I T G_{t-1}$ is the public investment in new capital of the previous period. We assume that $g_{k g}=\delta_{k g}$ in a business as usual scenario where the government chooses to maintain its public capital constant. This choice has an impact on public expenditure. The ITG variable allows us to capture the investment program to build new infrastructure in the economy. This program will increase the public capital stock compared to the previous period and produce a positive production externality $\left(\theta_{i}\right)$. This externality is introduced in the value added $\left(V a_{i}\right)$ equation:

$$
\text { 5. } V a_{i}=\theta_{i} A_{i} L d_{i}^{\alpha_{i}} K d_{i}^{1-\alpha_{i}}
$$

where $A_{i}$ is the scale parameter, $L d_{i}$, the labour demand, $K d_{i}$, the capital demand, and $\alpha$, the Cobb-Douglas parameter. Hence, an increase in $\theta_{i}$ represents a Hicks neutral productivity improvement, like the one modelled in Yeaple and Golub (2007). ${ }^{10}$ With this

\footnotetext{
${ }^{9}$ The values for this parameter were estimated using data from Quebec for the 1961-2008 period. The estimation approach used is the same as Harchaoui and Tarkhani (2003). In general, the values of our parameters are conservative with respect to this literature, ranging from 0.01 to 0.038 . See table A.1 in the appendix for specific parameter values. The complete results are forthcoming in Boccanfuso et al (2012). Given that parameters are below 1, the returns to public infrastructure are positive but the growth occurs at the decreasing rate. $\frac{\partial \theta}{\partial K G}>0$, et $\frac{\partial^{2} \theta}{\partial K G^{2}}<0$

${ }^{10}$ This formulation is also commonly used in studies estimating externalities of public infrastructure on total factor productivity such as Ashauer (1989), Gramlich (1994) and Dessus and Herrera (1996), among others.
} 
formulation, the infrastructure investment can act as a source of comparative advantage because the function is sector specific. It is important to understand that externalities from past public capital stock are calibrated in the $A_{i}$ parameter of the $V a_{i}$ function. The externality measure by $\theta_{i}$ represents the portion associated with the new investments of one billion per year for five years ${ }^{11}$.

As in Ballard et al. (1985), de Melo et Tarr (1992) and Blonigen et al. (1997) we assume an endogenous labour supply. The workers decide to work more (less) when the real wage increases (decreases) relative the reference period or the previous period which enables us to take into account the presence of equilibrium unemployment (Decaluwé et al., 2010). Representative households acquire their income from wages, interests, dividends and net transfers from the government and from abroad. As for expenditures, households pay taxes, save a fixed proportion of their disposable income, and spend the rest of this income on the consumption of goods and services. The firms receive the largest share of returns to capital paid by production branches, after deduction of depreciation of capital. Firms then pay taxes on their revenues, and dividends and interests to other agents. Governments obtain their revenues from income tax and indirect taxes. Their expenditures are composed of program expenses, transfer payments to other agents, and payments of interest on their debt. Government investment is financed by public savings and debt. All government balances are endogenous in the model and will positively or negatively affect its total savings.

Commodity markets are balanced through adjustments in market prices. The current account balance is fixed; accordingly, the nominal exchange rate varies to allow the real

\footnotetext{
${ }^{11}$ In fact, as we modeled we would capture the negative externalities of non maintenance of public infrastructure but we do not simulate such policies in the model.
} 
exchange rate to clear the current account balance. The GDP deflator is used as the numeraire in the model. We also assume in a standard manner that the Quebec economy is a small open economy. Armington's (1969) assumption is adopted for the demand of imported goods (imperfect substitution with constant elasticity of substitution function (CES)) and constant elasticity of transformation (CET) functions are used to model export supply. $^{12}$

Finally, private investment is endogenous and determined by the level of savings generated by households, firms, the current account balance, and the depreciation of capital. The savings of households is a fixed portion of its disposable income. For firms, it is a balance computed after the representative firm pays taxes, dividends, interests on its debt, and transfers to other agents and to the rest of the world. Government saves after having paid their purchases of goods and services, transfers to agents, and interest on its debt. Once the total level of private investment is determined, it is distributed between branches according to an investment decision rule that puts into relation the capital return and its cost. The new capital is added to the initial capital stock or the capital stock from the previous period as described in the dynamic of the following model.

\section{Dynamics of the model}

Using a recursive dynamic model implies taking into account the accumulation of capital and labour force, but also technological progress as well as the evolution of the debt (asset) of agents. The evolution of capital stock is modelled using investment demand

\footnotetext{
${ }^{12}$ The complete set of equations and variables can be provided upon request.
} 
$\left(\operatorname{Ind}_{i, t}\right)$ functions that link the rate of accumulation to the rate of capital return $\left(r_{i, t}\right)$ over its user cost $\left(U_{t}\right)$ (Equation 5) with a sector specific elasticity.

$$
\text { 6. } \operatorname{Ind}_{i, t}=\phi_{i}\left(\frac{r_{i, t}}{U_{t}}\right)^{\xi_{t}} K d_{i, t}
$$

The unit cost of capital $\left(U_{t}\right)$ is dependent of the $\left(\operatorname{Pinv}_{t}\right)$, the depreciation of capital and the interest rate given the following function:

$$
\text { 7. } U_{t}=\operatorname{Pinv}_{t}(i r+\delta)
$$

The level of investment demand at time $t$ is used in the dynamic loop of the model by means of the equation for the accumulation of capital to establish the capital stock at period $t+1$ as specified in the following equation:

$$
\text { 8. } K d_{i, t+1}=(1-\delta) K d_{i, t}+\operatorname{Ind}_{i, t}
$$

where $K d_{t+1}$ is the capital stock of period $t+1$ established by the sum of the depreciated capital stock of the preceding period $\left((1-\delta) * K d_{t}\right)$ and the investment decision $\left(I n d_{i, t}\right)$ at time $t$. Other adjustment mechanisms are also taken into account in the dynamic component of the model. Labour force growth $\left(L s_{t+l)}\right.$ is introduced in a standard fashion using population growth rate $(n)$ :

$$
\text { 9. } L s_{t+1}=(1+n) L s_{t}
$$

The population growth rate used is the one published by the Institut de la Statistique du Québec for the working age population (15 to 65 years old) for the 2006-2011 period ${ }^{13}$. In a standard fashion, we use the technological progress to calibrate our business as usual

\footnotetext{
13 The value is $0.67 \%$ and we rounded at $0.7 \%$ for use in the calibration of the model.
} 
2\% GDP growth rate. Other exogenous variables such as government transfers to households, current account balance and other are increased by the population growth rate from one period to the other. The government debt evolves according to public savings and public investment in infrastructure. This stock of debt determines the amount of interests to be paid by government to the various agents at each period.

\section{Simulation and analysis of results}

The main objective of our paper is to perform a comparative analysis of various funding schemes to implement the public investment program launched by the government of Quebec in 2007. This program consists of a \$1 billion investment on new infrastructure expenditures over five years. This amount is in addition to the program that aims to restore and maintain existing infrastructure. For the purposes of our comparative analysis, we performed five simulations. The first is a reference scenario (business as usual-BAU) that consists of running the model without the investment program but with the increase in growth variables; for the second, we simulate our investment program of one billion dollars for five years and we assume that the program if funded completely with debt. In the following three scenarios, we will assume that the cost of the infrastructure program will be funded in part with debt and in part with a tax increase. To have a comparable scenario for the three options, we imposed that the debt at the last period be the same for all options and that the increase be half of the option where debt funds the program completely. We investigate three tax options, namely an increase in the sales tax $(t x)$, an increase in the income tax (tym) and finally an increase on the business tax (tye). 
The reference year chosen is 2006, and the investment program is applied between 2007 and 2011. However, we solve the model over a longer period to analyze the effects at the end of the program. We pursue the resolution up to 2016. This will allow us to evaluate the program's impact from 2006 to 2016. The productivity shock simulated will come into effect in 2007, as we assume that the positive productivity effects occur after the construction of infrastructure. As a result, in the first year of investment, it is primarily the economic activity generated by construction that is propagated in the model. In our comparative analysis, we use the expressions "business as usual” (reference scenario) for simulation 1, "scenario1" for the simulation where the funding comes from debt, "scenario2" for the simulation in which we partly fund the program with the sales tax, "scenario3" for the simulation where half of the program is funded with the income tax and finally the "scenario 4," where the program is partially funded with a business tax ${ }^{14}$. The scenarios are presented in Table 1.

Table 1: Presentation of simulations

\begin{tabular}{|c||l|}
\hline Code & \multicolumn{1}{c|}{ Simulations presentation } \\
\hline \hline BAU & Growth of 2\% per year of the 2006-2016 period $(\mathrm{t}-\mathrm{t}+10)$ \\
\hline scenario1 & 1 billions \$ investment program of 5 years funded $100 \%$ by debt \\
\hline scenario2 & 1 billions \$ investment program of 5 years funded by debt \& by sales tax (tx) \\
\hline scenario3 & 1 billions \$ investment program of 5 years funded by debt \& by household income tax (tym) \\
\hline scenario4 & 1 billions \$ investment program of 5 years funded by debt \& by business tax (tye) \\
\hline \hline
\end{tabular}

\section{Analysis of results}

We present the results of our comparative analysis in relation to the BAU simulation. It should be kept in mind that the reference scenario (BAU) does not include the shock on

\footnotetext{
${ }^{14}$ We could have used various approaches to consider the 50/50 funding. We selected to have an average deficit of 50\% of the simulation over the whole period of 2006-2016 compared to when the debt funds the entire program. In fact, it is not completely appropriate to day that the debt entirely funds the program since the growth generated will contribute more income for government and hence more savings reducing the needs to borrow in subsequent periods.
} 
public investments in infrastructures, while this is the case for the other simulations. We will first analyse some key macroeconomic variables and two sectoral variables. For the macroeconomic variables, we present their path throughout the simulation while for sectoral variables results are presented for the last period $\left(\mathrm{t}+10\right.$ or 2016) ${ }^{15}$.

\section{Scenario 1: Investment program funded by debt}

Ceteris paribus, an increase in public investment will raise the production by the construction sector and produce externalities in subsequent periods in the model. As we can see from table 2, the growth generated by the construction of the new infrastructure is very small with an increase in economic activity of $0.003 \%$ compared to the BAU scenario. This is followed by growth generated by externalities of the investment program at $0.342 \%$ for the second year to a maximum of $0.642 \%$ at the last year of the investment program (2011) and as we move further in time the externalities effects are reduced given the depreciation of the public capital.

Table 2: GDP gap compared to BAU scenario

\begin{tabular}{|c|c|c|c|c|c|c|c|c|c|c|}
\hline $\begin{array}{c}\text { Gross domestic } \\
\text { product (GDP) }\end{array}$ & $\begin{array}{l}2007 \\
(t+1)\end{array}$ & $\begin{array}{l}2008 \\
(t+2)\end{array}$ & $\begin{array}{l}2009 \\
(t+3)\end{array}$ & $\begin{array}{l}2010 \\
(t+4)\end{array}$ & $2011(t+5)$ & $\begin{array}{l}2012 \\
(t+6)\end{array}$ & $2013(t+7)$ & $\begin{array}{l}2014 \\
(t+8)\end{array}$ & $2015(t+9)$ & $\begin{array}{c}2016 \\
(t+10)\end{array}$ \\
\hline scenario1 (debt) & 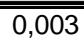 & 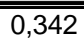 & $0,0,455$ & $0,0,555$ & 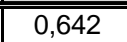 & 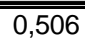 & "0,486 & 0,455 & 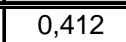 & (0,357 \\
\hline scenario2 (tx) & 0,003 & 0,344 & 0,459 & 0,560 & 0,649 & 0,512 & 0,493 & 0,461 & 0,417 & 0,363 \\
\hline scenario3 (tym) & 0,003 & 0,344 & 0,459 & 0,560 & 0,649 & 0,514 & 0,496 & 0,466 & 0,423 & 0,370 \\
\hline scenario4 (tye) & 0,003 & 0,335 & 0,442 & 0,535 & 0,616 & 0,481 & 0,463 & 0,433 & 0,391 & 0,337 \\
\hline
\end{tabular}

It is important to highlight that the funding of the pro/gram is not completely or dollars for dollars funded by debt since the growth effects will increase government income and hence funding needs are bellow the 1 billions $\$$ of the investment program. We can see from table 3 bellow that government income decreases in the first period given the fact that no growth is generated compared to the BAU (-0.276\%) during that period but the

\footnotetext{
${ }^{15}$ Presenting results for 24 sectors over 11 periods would have been too cumbersome.
} 
government income grows faster afterward to a maximum at the end of the investment program in 2011 with a $0.511 \%$ positive gap in growth.

Table 3: Gap compared to BAU scenario for government income (Yg)

\begin{tabular}{|c||c|c|c|c|c|c|c|c|c|c|c|}
\hline $\begin{array}{c}\text { Government } \\
\text { income (Yg) }\end{array}$ & $\begin{array}{c}\mathbf{2 0 0 6} \\
\mathbf{( t )}\end{array}$ & $\begin{array}{c}\mathbf{2 0 0 7} \\
\mathbf{( t + 1 )}\end{array}$ & $\begin{array}{c}\mathbf{2 0 0 8} \\
\mathbf{( t + 2 )}\end{array}$ & $\begin{array}{c}\mathbf{2 0 0 9} \\
\mathbf{( t + 3 )}\end{array}$ & $\begin{array}{c}\mathbf{2 0 1 0} \\
\mathbf{( t + 4 )}\end{array}$ & $\begin{array}{c}\mathbf{2 0 1 1} \\
(\mathbf{t}+5)\end{array}$ & $\begin{array}{c}\mathbf{2 0 1 2} \\
(\mathbf{t}+\mathbf{6})\end{array}$ & $\begin{array}{c}\mathbf{2 0 1 3} \\
(\mathbf{t}+\mathbf{7})\end{array}$ & $\begin{array}{c}\mathbf{2 0 1 4} \\
(\mathbf{t}+\mathbf{8})\end{array}$ & $\begin{array}{c}\mathbf{2 0 1 5} \\
(\mathbf{t}+9)\end{array}$ & $\begin{array}{c}\mathbf{2 0 1 6} \\
(\mathbf{t}+\mathbf{1 0})\end{array}$ \\
\hline \hline scenario1 (debt) & $-0,276$ & 0,091 & 0,217 & 0,329 & 0,428 & 0,541 & 0,520 & 0,487 & 0,440 & 0,382 & 0,314 \\
\hline scenario2 (tx) & $-0,162$ & 0,207 & 0,336 & 0,450 & 0,550 & 0,548 & 0,527 & 0,493 & 0,446 & 0,387 & 0,319 \\
\hline scenario3 (tym) & $-0,222$ & 0,146 & 0,275 & 0,388 & 0,488 & 0,604 & 0,584 & 0,552 & 0,506 & 0,449 & 0,382 \\
\hline scenario4 (tye) & $-0,116$ & 0,245 & 0,365 & 0,470 & 0,563 & 0,516 & 0,496 & 0,464 & 0,418 & 0,361 & 0,294 \\
\hline
\end{tabular}

The increase in income is directly influence by the stronger economic activity generated by higher productivity of our factors and more employment generated with this growth.

As for the public debt (table 4), since it contributes to funding the infrastructure program, we observe in increase starting in the second period (a deficit is observed in the first period and added to the debt in the following period). The debt further increases up to 2010 and thereafter; the gap with the BAU starts to decrease even if funding needs are still present in 2011. This is explained by the stronger growth in 2011 compared to the BAU and this growth provides sufficient additional government revenues to fund the program.

Table 4: Gap compared to BAU scenario for public debt

\begin{tabular}{|c||c|c|c|c|c|c|c|c|c|c|c|}
\hline $\begin{array}{c}\text { Public Debt } \\
\text { (debt) }\end{array}$ & $\begin{array}{c}\mathbf{2 0 0 6} \\
(\mathbf{t})\end{array}$ & $\begin{array}{c}\mathbf{2 0 0 7} \\
(\mathbf{t}+\mathbf{1})\end{array}$ & $\begin{array}{c}\mathbf{2 0 0 8} \\
(\mathbf{t}+\mathbf{2})\end{array}$ & $\begin{array}{c}\mathbf{2 0 0 9} \\
(\mathbf{t}+\mathbf{3})\end{array}$ & $\begin{array}{c}\mathbf{2 0 1 0} \\
(\mathbf{t}+\mathbf{4})\end{array}$ & $\begin{array}{c}\mathbf{2 0 1 1} \\
(\mathbf{t}+5)\end{array}$ & $\begin{array}{c}\mathbf{2 0 1 2} \\
(\mathbf{t}+\mathbf{6})\end{array}$ & $\begin{array}{c}\mathbf{2 0 1 3} \\
(\mathbf{t}+\mathbf{7})\end{array}$ & $\begin{array}{c}\mathbf{2 0 1 4} \\
(\mathbf{t}+\mathbf{8})\end{array}$ & $\begin{array}{c}\mathbf{2 0 1 5} \\
(\mathbf{t}+\mathbf{9})\end{array}$ & $\begin{array}{c}\mathbf{2 0 1 6} \\
(\mathbf{t}+\mathbf{1 0})\end{array}$ \\
\hline \hline scenario1 (debt) & 0,000 & 1,787 & 2,456 & 3,047 & 3,565 & 3,204 & 2,840 & 2,483 & 2,150 & 1,854 & 1,609 \\
\hline scenario2 (tx) & 0,000 & 1,577 & 2,128 & 2,592 & 2,974 & 2,580 & 2,182 & 1,790 & 1,420 & 1,087 & 0,804 \\
\hline scenario3 (tym) & 0,000 & 1,686 & 2,298 & 2,827 & 3,278 & 2,845 & 2,403 & 1,963 & 1,540 & 1,150 & 0,804 \\
\hline scenario4 (tye) & 0,000 & 1,499 & 2,021 & 2,461 & 2,825 & 2,456 & 2,082 & 1,715 & 1,370 & 1,062 & 0,804 \\
\hline
\end{tabular}

If we analyse the sectoral impact of the first simulation (see table 5), we can highlight that the agriculture sector and construction sectors are the ones benefiting the most with a positive gap of $0.47 \%$ compared to the BAU scenario.

Table 5: Gap compared to BAU scenario for total output at the end of resolution $(\mathrm{t}+10)$ 


\begin{tabular}{|l||c|c|c|c||}
\hline \multicolumn{1}{|c|}{ Value added (total output) } & $\begin{array}{c}\text { scenario1 } \\
\text { (debt) }\end{array}$ & $\begin{array}{c}\text { scenario2 } \\
\text { (tx) }\end{array}$ & $\begin{array}{c}\text { scenario3 } \\
\text { (tym) }\end{array}$ & $\begin{array}{c}\text { scenario4 } \\
\text { (tye) }\end{array}$ \\
\hline \hline Agriculture & 0,47 & 0,48 & 0,50 & 0,44 \\
\hline Forestry & 0,35 & 0,36 & 0,38 & 0,33 \\
\hline Fishing/hunting & 0,25 & 0,26 & 0,27 & 0,23 \\
\hline Agric\&forestry support & 0,36 & 0,36 & 0,38 & 0,33 \\
\hline Mining & 0,47 & 0,48 & 0,51 & 0,44 \\
\hline Utilities & 0,39 & 0,40 & 0,41 & 0,36 \\
\hline Construction & 0,47 & 0,47 & 0,51 & 0,44 \\
\hline Manufacturing & 0,36 & 0,36 & 0,38 & 0,33 \\
\hline Wholesale retail & 0,40 & 0,41 & 0,42 & 0,38 \\
\hline Detail retail & 0,24 & 0,25 & 0,24 & 0,23 \\
\hline Transport \& storage & 0,33 & 0,34 & 0,35 & 0,31 \\
\hline Information\&cultural industries & 0,37 & 0,38 & 0,39 & 0,35 \\
\hline Finance/insurance/realestate & 0,37 & 0,38 & 0,38 & 0,34 \\
\hline professional\&scientific services & 0,37 & 0,38 & 0,39 & 0,35 \\
\hline administrative services & 0,31 & 0,31 & 0,32 & 0,29 \\
\hline educational services & 0,31 & 0,31 & 0,31 & 0,29 \\
\hline health \& social services & 0,25 & 0,25 & 0,25 & 0,23 \\
\hline arts \& leasure & 0,32 & 0,33 & 0,32 & 0,30 \\
\hline hotel \& restaurents & 0,23 & 0,23 & 0,22 & 0,21 \\
\hline other private services & 0,25 & 0,26 & 0,26 & 0,23 \\
\hline office, cafeteria\& lab furnitures & 0,29 & 0,29 & 0,30 & 0,27 \\
\hline Tourism and publicity & 0,32 & 0,32 & 0,33 & 0,30 \\
\hline non profit orginazations & 0,13 & 0,13 & 0,11 & 0,12 \\
\hline public services & 0,05 & 0,05 & 0,05 & 0,05 \\
\hline
\end{tabular}

The ones benefiting the least outside the public sector, we have the non profit organisation sector $(+0.13 \%)$ and the hotel and restaurant $(+0.23 \%)$. As for rental rate of capital (table 6), most of them decrease compared to the BAU, with the stronger gap found for the health sector $(-0.41 \%)$ and we have no change compared to the BAU for the agriculture \& forestry support sector and mining sector. 
Table 6: Gap compared to BAU scenario for rental rate of capital at $\mathrm{t}+10$

\begin{tabular}{|l||c|c|c|c||}
\hline \multicolumn{1}{|c|}{ Rental rate of capital } & $\begin{array}{c}\text { scenario1 } \\
\text { (debt) }\end{array}$ & $\begin{array}{c}\text { scenario2 } \\
\text { (tx) }\end{array}$ & $\begin{array}{c}\text { scenario3 } \\
\text { (tym) }\end{array}$ & $\begin{array}{c}\text { scenario4 } \\
\text { (tye) }\end{array}$ \\
\hline \hline Agriculture & $-0,20$ & $-0,20$ & $-0,20$ & $-0,10$ \\
\hline Forestry & $-0,10$ & $-0,10$ & $-0,10$ & $-0,10$ \\
\hline Fishing/hunting & $-0,10$ & $-0,10$ & $-0,10$ & 0,00 \\
\hline Agric\&forestry support & 0,00 & 0,00 & 0,00 & 0,00 \\
\hline Mining & 0,00 & 0,00 & 0,00 & 0,00 \\
\hline Utilities & $-0,20$ & $-0,20$ & $-0,30$ & $-0,10$ \\
\hline Construction & $-0,10$ & $-0,20$ & $-0,10$ & $-0,10$ \\
\hline Manufacturing & $-0,10$ & $-0,10$ & $-0,10$ & 0,00 \\
\hline Wholesale retail & $-0,10$ & $-0,10$ & $-0,10$ & $-0,10$ \\
\hline Detail retail & $-0,20$ & $-0,20$ & $-0,20$ & $-0,10$ \\
\hline Transport \& storage & $-0,10$ & $-0,10$ & $-0,10$ & 0,00 \\
\hline Information\&cultural industries & $-0,20$ & $-0,20$ & $-0,20$ & $-0,10$ \\
\hline Finance/insurance/realestate & $-0,20$ & $-0,20$ & $-0,20$ & $-0,10$ \\
\hline professional\&scientific services & $-0,10$ & $-0,10$ & $-0,20$ & $-0,10$ \\
\hline administrative services & $-0,10$ & $-0,10$ & $-0,20$ & $-0,10$ \\
\hline educational services & $-0,20$ & $-0,20$ & $-0,30$ & $-0,20$ \\
\hline health \& social services & $-0,41$ & $-0,51$ & $-0,62$ & $-0,41$ \\
\hline arts \& leasure & $-0,10$ & $-0,10$ & $-0,20$ & $-0,10$ \\
\hline hotel \& restaurents & $-0,10$ & $-0,10$ & $-0,20$ & $-0,10$ \\
\hline other private services & $-0,10$ & $-0,10$ & $-0,20$ & $-0,10$ \\
\hline office, cafeteria\& lab furnitures & $-0,20$ & $-0,20$ & $-0,30$ & $-0,20$ \\
\hline Tourism and publicity & $-0,20$ & $-0,20$ & $-0,30$ & $-0,20$ \\
\hline non profit orginazations & $-0,20$ & $-0,20$ & $-0,20$ & $-0,10$ \\
\hline public services & $-0,29$ & $-0,29$ & $-0,39$ & $-0,20$ \\
\hline
\end{tabular}

Finally, the stronger economic activity generates more export at the end of the period of resolution (2016) with the strongest gaps observed for the health and social services (0.66\%) and agriculture $(0.63 \%)$ and the weakest gap for the non profit organisation sector (+0.04\%) and hotel \& restaurants (+0.24\%).

Table 7: Gap compared to BAU scenario for exports at the end of resolution $(\mathrm{t}+10)$

\begin{tabular}{|l||c|c|c|c|}
\hline \multicolumn{1}{|c|}{ Exports } & $\begin{array}{c}\text { scenario1 } \\
\text { (debt) }\end{array}$ & $\begin{array}{c}\text { scenario2 } \\
\text { (tx) }\end{array}$ & $\begin{array}{c}\text { scenario3 } \\
\text { (tym) }\end{array}$ & $\begin{array}{c}\text { scenario4 } \\
\text { (tye) }\end{array}$ \\
\hline \hline Agriculture & 0,41 & 0,43 & 0,48 & 0,36 \\
\hline Forestry & 0,31 & 0,32 & 0,36 & 0,27 \\
\hline Fishing/hunting & 0,22 & 0,23 & 0,25 & 0,18 \\
\hline Agric\&forestry support & 0,31 & 0,32 & 0,36 & 0,27 \\
\hline Mining & 0,41 & 0,43 & 0,49 & 0,36 \\
\hline Utilities & 0,34 & 0,36 & 0,38 & 0,29 \\
\hline Construction & 0,41 & 0,43 & 0,51 & 0,37 \\
\hline Manufacturing & 0,31 & 0,32 & 0,37 & 0,27 \\
\hline Wholesale retail & 0,35 & 0,36 & 0,39 & 0,32 \\
\hline Detail retail & 0,21 & 0,22 & 0,21 & 0,19 \\
\hline Transport \& storage & 0,29 & 0,30 & 0,32 & 0,26 \\
\hline Information\&cultural industries & 0,32 & 0,33 & 0,36 & 0,29 \\
\hline Finance/insurance/realestate & 0,32 & 0,34 & 0,36 & 0,28 \\
\hline professional\&scientific services & 0,33 & 0,34 & 0,37 & 0,30 \\
\hline administrative services & 0,27 & 0,28 & 0,30 & 0,24 \\
\hline educational services & 0,27 & 0,27 & 0,28 & 0,24 \\
\hline health \& social services & 0,22 & 0,22 & 0,23 & 0,19 \\
\hline arts \& leasure & 0,28 & 0,29 & 0,28 & 0,25 \\
\hline hotel \& restaurents & 0,20 & 0,20 & 0,19 & 0,17 \\
\hline other private services & 0,22 & 0,23 & 0,23 & 0,19 \\
\hline non profit orginazations & 0,11 & 0,11 & 0,07 & 0,10 \\
\hline public services & 0,04 & 0,04 & 0,04 & 0,05 \\
\hline
\end{tabular}




\section{Scenario 2, 3 and 4}

In this subsection, we analyse simultaneously the three alternative taxes that are used to fund the investment program jointly with the debt. The first important observation for our comparative analysis is that the three taxes produce similar effects for most macroeconomic and sectoral variables. For some, it is difficult to distinguish lines in graphs of the gap between the scenarios and the BAU. The most obvious case is the GDP as is shown in figure 4.

Figure 4: Real GDP - Relative variation compared to the reference simulation

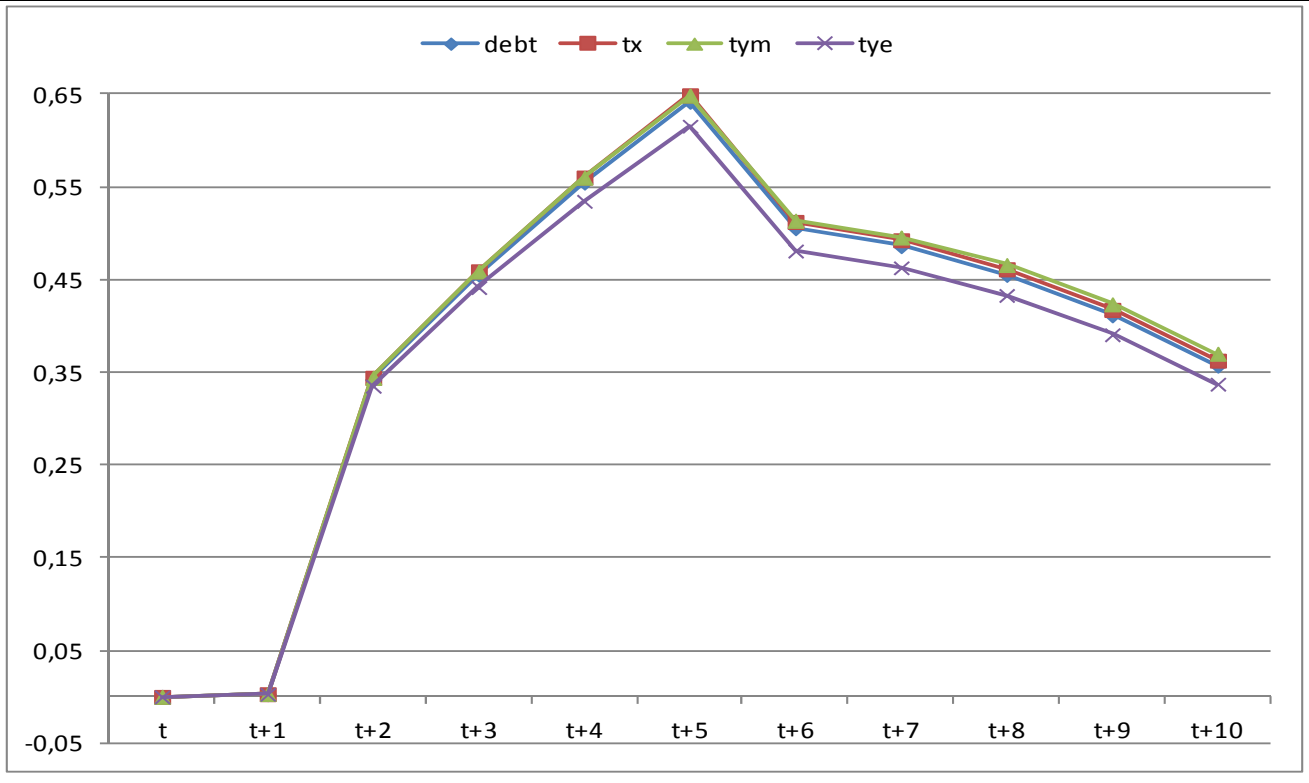

For all scenarios up to $t+2$, all lines are similar, from $t+2$ to $t+5$ (end of the program), only one line increases at a slower pace compared to the three other scenario, namely the business tax (tye), which produces a smaller growth and this is explained by the eviction effect where firms would have used these funds for private investment and this trend is 
confirmed and amplified after the end of the program. To distinguish the differentiated impact between debt, income tax and sales tax, it is easier to use the figures in table 2, and these reveal that the dominant option is the one where income tax is used, followed by sales tax and finally debt ranks third (before the business tax). However, we need to recall that with this option, we end our scenarios with a higher debt compared with the other option ${ }^{16}$. Other macroeconomic variables produce larger differences between the three funding options. Among these, we will look at the government income, the household real disposable income and the government debt level. For the government income (see table 3 above and figure 5 below), we have a difference directly at the start of the resolution for period $t$ and the gap increases after $t+1$ and stays relatively constant up to $\mathrm{t}+4$. In this case, the business tax is the one brining in the most revenue, followed by the sales tax and last the household income. After this period, the household income tax has the greatest gap followed by the sales tax and last we have the business tax and this trend remains constant till the end of the resolution. The income tax seems to be the best option to generate more government income to fund the program and the business tax the worst. It is important to recall that the tax rates are increase only temporarily during the investment program.

\footnotetext{
${ }^{16}$ For this reason, we cannot really conclude that debt is a better option compared to the business tax as reimbursing in the future will have a negative impact on many variables. Our objective is to emphasis the comparative analysis of the three taxes.
} 
Figure 5 - Government income - Variation compared to BAU

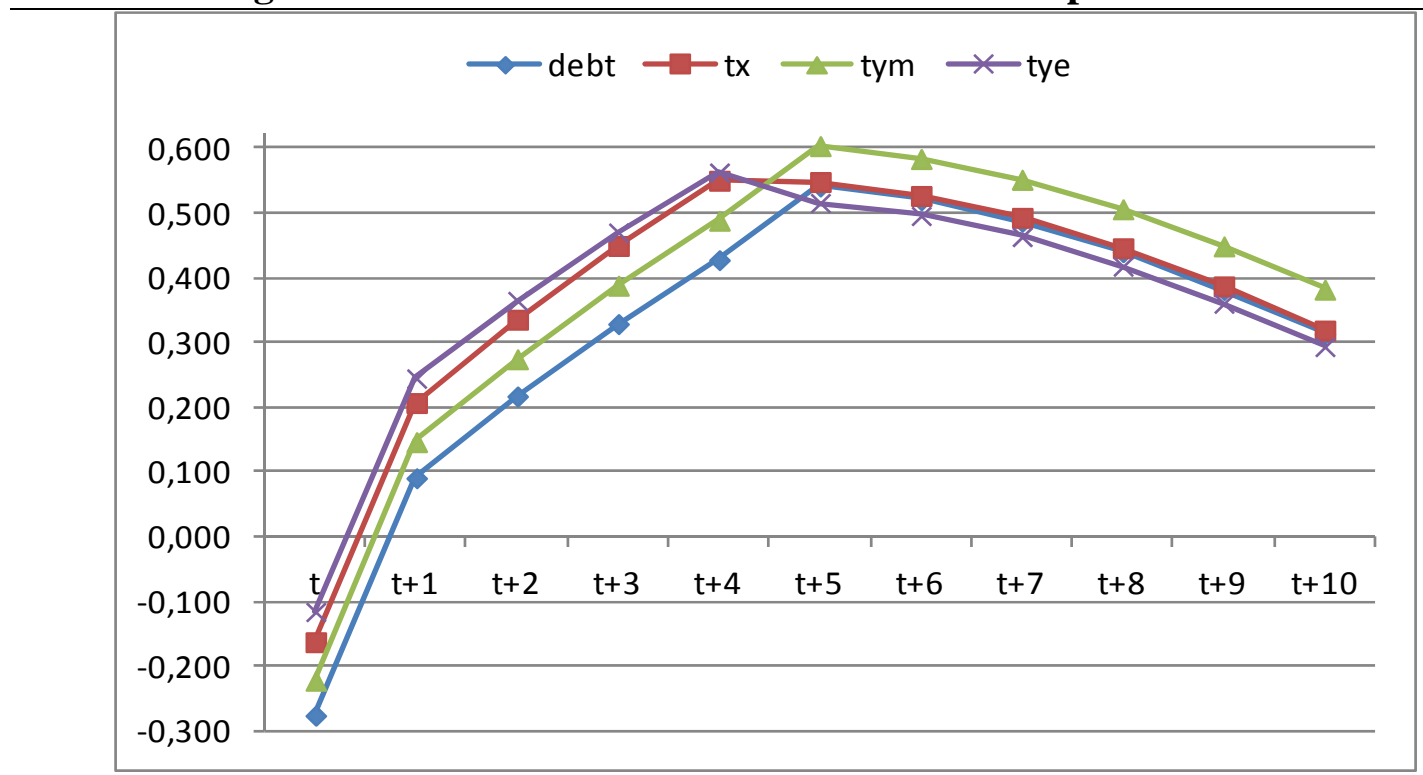

A similar finding is observed when analysing the household real income. In this case, if we look at table 8 and figure 6 below, we see that the household income tax has the strongest negative gap compared to the BAU followed by the sales tax and the business tax at the start of the resolution, for the second period, the gap becomes positive for the three options and the business tax is now the one with the greatest gap, followed by the income tax, and the sales tax, this trend remains the same up to $t+3$ and from there the income tax slightly becomes the best option, but this gap amplifies after the program to the end of the resolution.

Table 8: Gap compared to BAU scenario for aggregate household real income

\begin{tabular}{|l||c|c|c|c|c|c|c|c|c|c|c|}
\hline $\begin{array}{c}\text { Agregate } \\
\text { household } \\
\text { disposable real } \\
\text { income(Ydh/CPI) }\end{array}$ & $\begin{array}{c}\mathbf{2 0 0 6} \\
\mathbf{( t )}\end{array}$ & $\begin{array}{c}\mathbf{2 0 0 7} \\
\mathbf{( t + 1 )}\end{array}$ & $\begin{array}{c}\mathbf{2 0 0 8} \\
\mathbf{( t + 2 )}\end{array}$ & $\begin{array}{c}\mathbf{2 0 0 9} \\
\mathbf{( t + 3 )}\end{array}$ & $\begin{array}{c}\mathbf{2 0 1 0} \\
\mathbf{( t + 4 )}\end{array}$ & $\begin{array}{c}\mathbf{2 0 1 1} \\
\mathbf{( t + 5 )}\end{array}$ & $\begin{array}{c}\mathbf{2 0 1 2} \\
\mathbf{( t + 6 )}\end{array}$ & $\begin{array}{c}\mathbf{2 0 1 3} \\
\mathbf{( t + 7 )}\end{array}$ & $\begin{array}{c}\mathbf{2 0 1 4} \\
\mathbf{( t + 8 )}\end{array}$ & $\begin{array}{c}\mathbf{2 0 1 5} \\
\mathbf{( t + 9 )}\end{array}$ & $\begin{array}{c}\mathbf{2 0 1 6} \\
\mathbf{( t + 1 0 )}\end{array}$ \\
\hline scenario1(debt) & $-0,150$ & 0,185 & 0,170 & 0,220 & 0,270 & 0,294 & 0,286 & 0,291 & 0,283 & 0,264 & 0,235 \\
\hline scenario2 (tx) & $-0,134$ & 0,166 & 0,153 & 0,204 & 0,257 & 0,264 & 0,293 & 0,297 & 0,289 & 0,270 & 0,241 \\
\hline scenario3 (tym) & $-0,163$ & 0,176 & 0,163 & 0,214 & 0,265 & 0,313 & 0,307 & 0,312 & 0,306 & 0,288 & 0,261 \\
\hline scenario4 (tye) & $-0,127$ & 0,198 & 0,177 & 0,220 & 0,263 & 0,264 & 0,262 & 0,268 & 0,262 & 0,243 & 0,216 \\
\hline
\end{tabular}


Once again, we have the income tax that dominates, the sales tax which dominates the business tax. The sales tax is the least interesting option for the households during the period since it causes a price hike that can be observed in table XX and graph YY.

Figure 6 - Household disposable real income - Variation compared to BAU

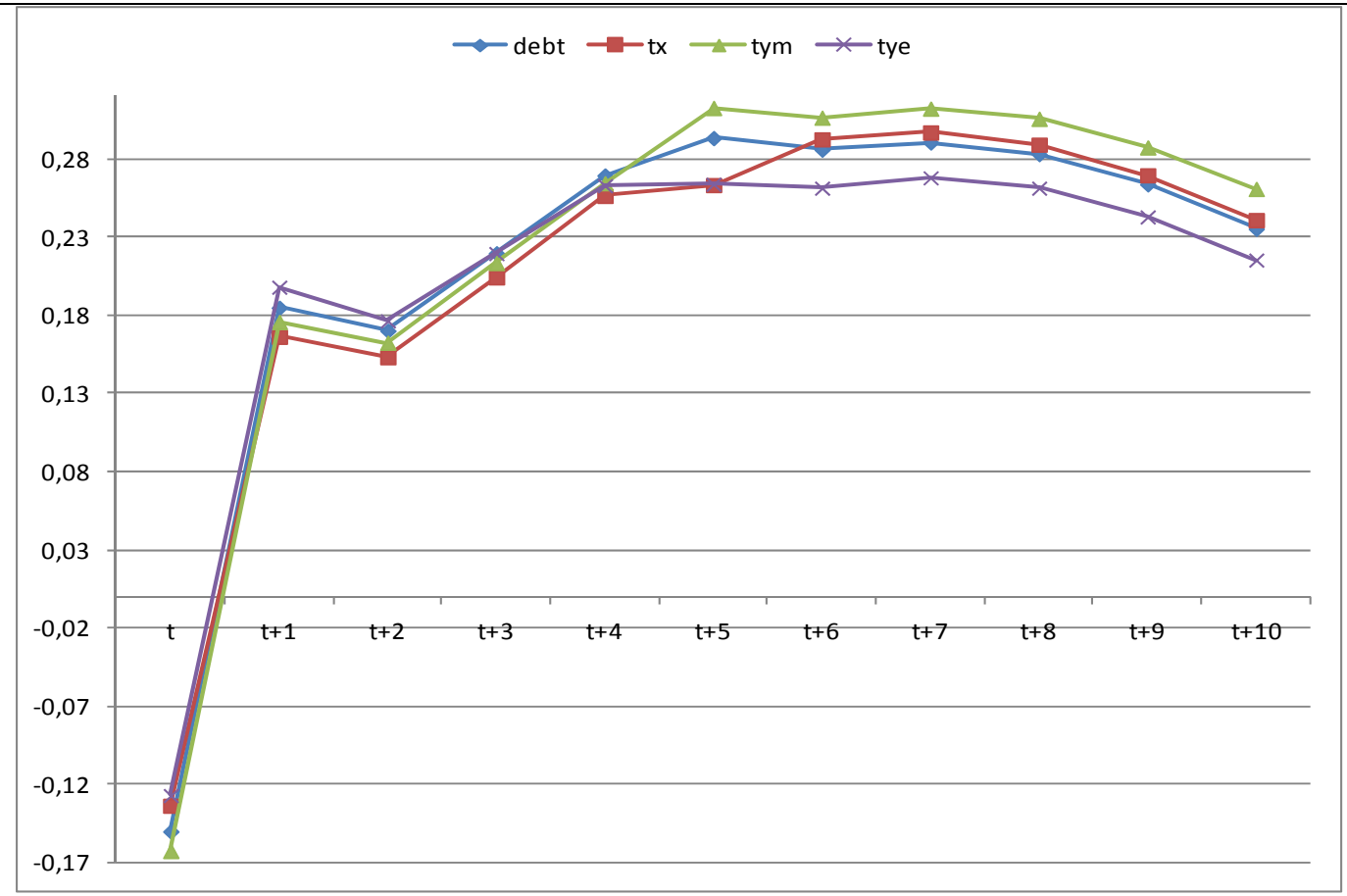

When moving to public debt (table 4 above and figure 7 below), we imposed that the starting point and the end result be the same for comparative purpose. However, we notice right from period $t+1$ that the positive gap, increases faster for the income tax, followed by the sales tax and finally the business tax and this to the maximum gap observed at $\mathrm{t}+4$ and the gap decreases thereafter until the end of the resolution where the debt level is imposed to be the same for all funding options. 
Figure 7 - Public debt - Variation compared to BAU

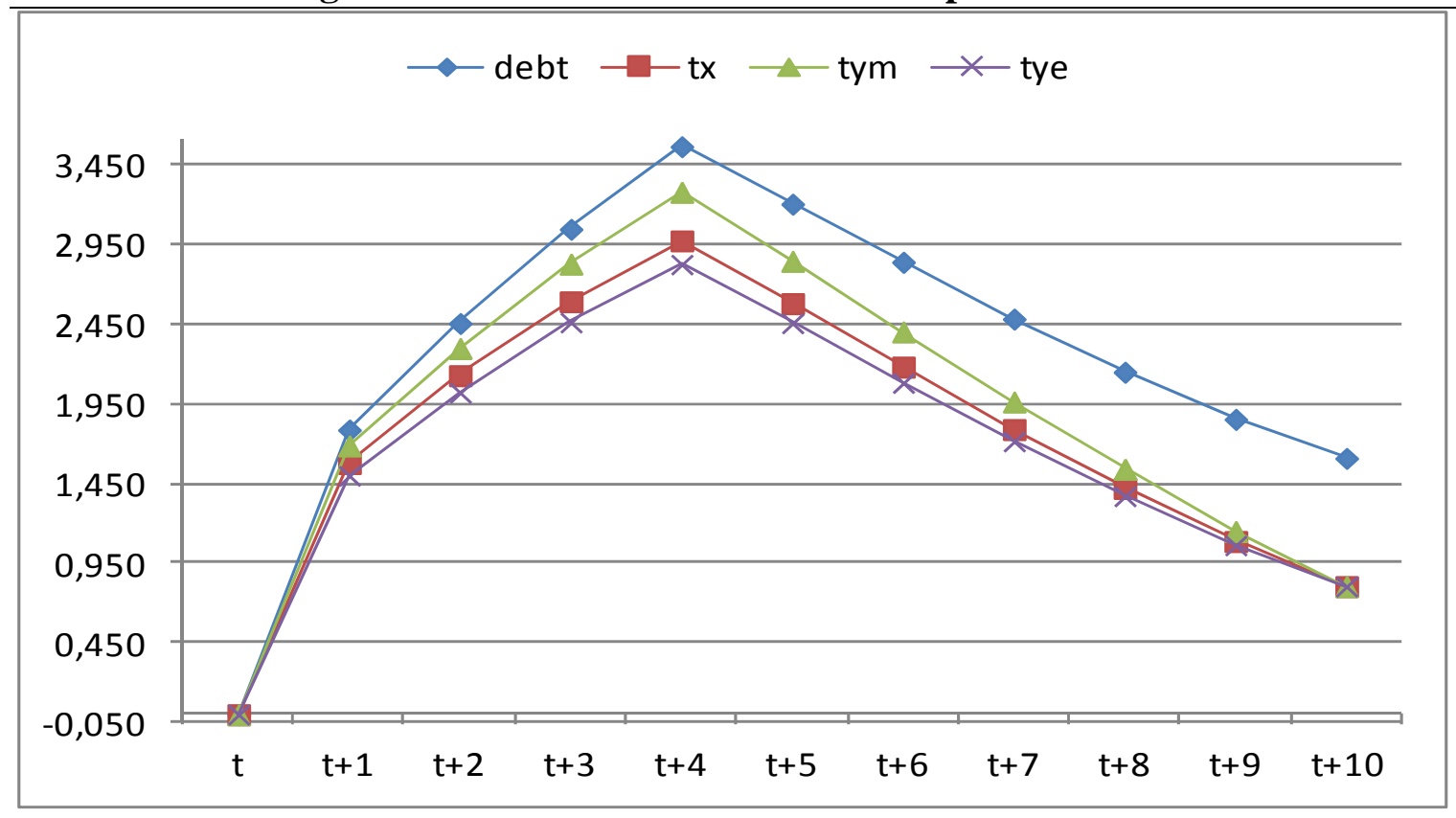

Finally, we can mention that the consumer price index (CPI) as is seen in figure 8 below decreases slightly for period $t+1$ and increases till the end of the program and as expected the sales tax produces stronger price effects during the program compared to the BAU and compared to the other funding options. The business tax produces the second strongest effects but the gap is much smaller compared to the income tax option. The income tax option is the one that is consistently below all other options throughout the resolution. 
Figure 8 - Consumer price index - Variation compared to BAU

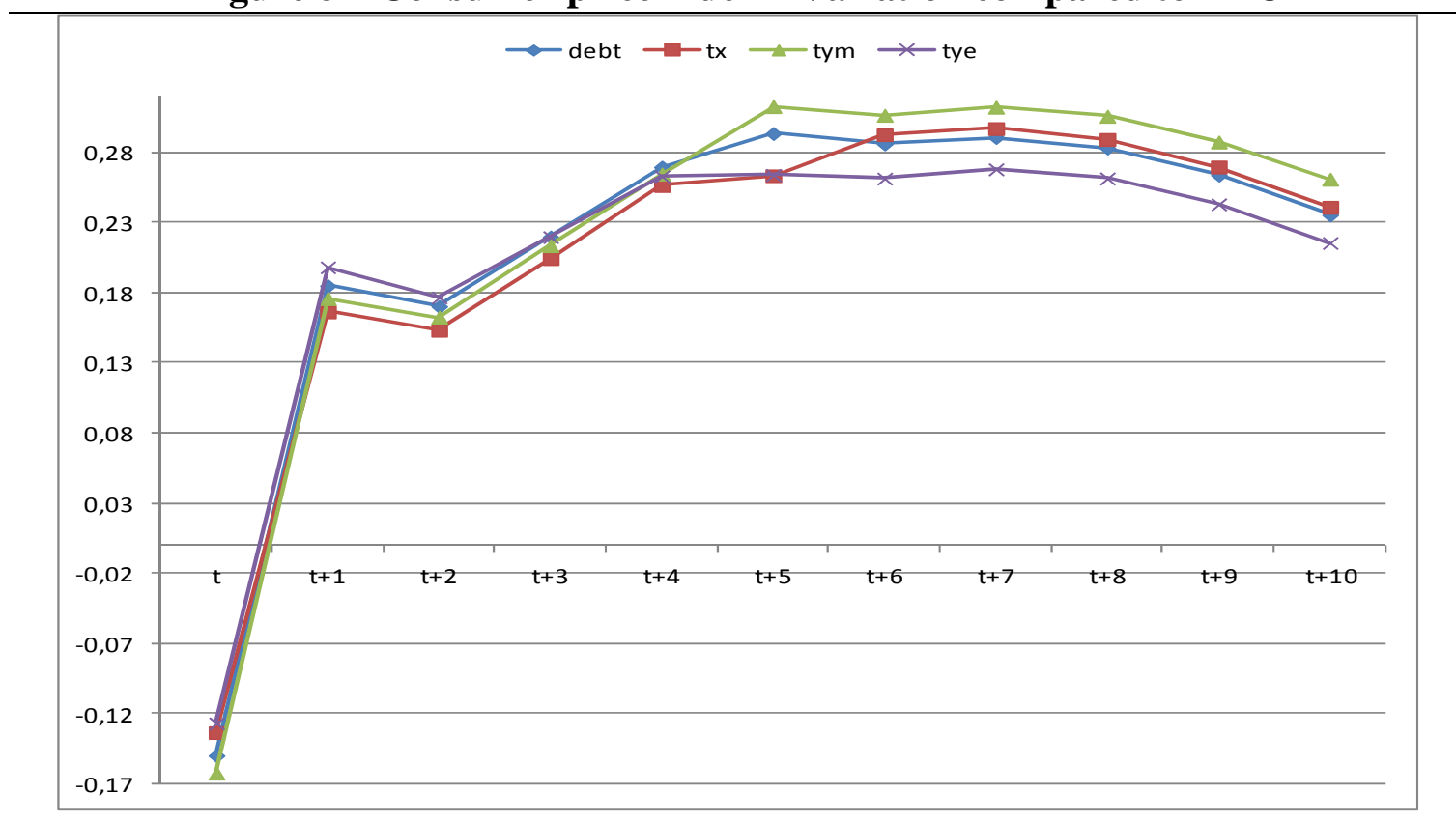

The sectoral effects for production generate a relatively clear indication that the worst option is with the business tax. This funding option produces the least favourable results in terms of production for all sectors except the public sector. On its part, the household income tax option is the most favourable option for 18 of 24 sectors for total production and the sales tax, is best for 5 of 24 sectors. For rental rate of capital, the gaps are smaller but in this case the business tax is the one producing the weakest negative impact compared to the BAU for the most sectors with 11 out of 24 an for other sectors it produce an impact equal to the sales tax except for the construction sector where the impact is equal to the household income tax. The least favourable option here would be the household income tax option with 11 out of 24 sectors that experience the strongest negative impact compared to the BAU scenario. 
For the exports, as we can observe in table $\mathrm{XX}$, the ranking of the effects for the sectors is not modified for the 3 most favored sectors (health and social services, agriculture and finance \& insurance sectors. As with other variables, the business tax is the least favourable for exports since the lowest increases compared to the BAU is observed for 22 out of 24 sectors. The most favourable option is the household income tax with a dominant effect for 21 of the 23 sectors.

\section{Conclusion}

In 2007, the Quebec government launched the Programme d'infrastructures Québec (PIQ), one of the broadest infrastructure investment programs in the history of the province. The program aimed to nullify a maintenance deficit of $\$ 27$ billion and to improve the stock of infrastructures in Quebec. In general, the literature on the subject supports that these public infrastructure expenditures contribute positively to the productivity of the private sector albeit not unanimously. In addition, Savard and Adjovi (1998) show that using weak public expenditure externalities in a CGE model can reverse a number of results in an economic impact analysis compared to an analysis in which these externalities are not taken into account. In this context, we constructed a sequential dynamic CGE model for the Quebec economy with the assumption that new infrastructure will generate productivity gains in the private sectors in line with the partial equilibrium literature on this issue. We have estimated sector specific elasticities for the Quebec economy based on the approach proposed and applied by Harchaoui and Tarkhani (2003) for the Canadian economy using data ranging from 1961 to 2009. 
We extended on the existing literature by using a dynamic approach as opposed to Estache et al (2010) or Savard and Adjovi (1998), we use a much richer (endogenous labour supply among other things) and propose a disaggregated model compared to Adam and Beven (2006) and Levy (2007).

We have conducted a comparative analysis of three funding options to scale up infrastructure in the Quebec economy. We first simulate a scenario where debt is used to fund the infrastructure program and we investigate using a sales tax, income tax and business tax increases to fund half of the infrastructure investment program with debt funding the remainder of the program. Our findings reveal that in terms of growth, the various funding options do not produce large differences. This finding is coherent with Boccanfuso et al (2009) and Estache et al (2010). In spite of the small differences, we differences between the funding options and the best option to fund the program is the household income tax option followed by the sales tax and the worst option is the sales tax. This conclusion holds from most macroeconomic variables we presented and for sectoral variables. The exception to this conclusion is with the consumer price index where the household income tax has the largest effect especially after the investment program and for the rental rate of capital where this option has a stronger negative impact on returns to capital.

In is important to raise a few caveats with respect to our results. First, we use a sequential dynamic model for our analysis and this implies intertemporal independence of the utility function of the aggregate consumer. This specificity of the model and other simplyfing assumption will not allow to capture all types of distortions associated with the three 
taxes we analysed. For example, increasing sales tax could push the households to push consumption in the future to save more at present. This would increase private investment and favour growth earlier on in the resolution of the model.

Capturing these features in a dynamic model of rational expectation would be done at the cost of some sectoral disaggregation. We plan to extend the model at the micro behaviour level to attempt to capture more tax distortions among other things.

\section{References}

Abdullatif E. (2006), " Crowding-out and crowding-in effects of government bonds market on private sector investment: a Japanese case study ", Institute of Developing Economies, Discussion paper, $\mathrm{n}^{\circ} 74$.

Adam C. and D. Bevan (2006), " Aid and the Supply Side: Public Investment, Export Performance, and Dutch Disease in Low-Income Countries », The World Bank Economic Review, Vol. 20, n²2, pp. 261 à 290.

Ahmed H. and S.M. Miller (1999), " Crowding-In and Crowding-out Effect of the Components of Government Expenditure ", Department of Economics, University of Connecticut, Working paper, $\mathrm{n}^{\circ}$ 1999-02.

Armington P. S. (1969) «A Theory of Demand for Products Distinguished by Place of Production », IMF staff paper, 16(1), pp. 159-178.

Aschauer D. A. (1989), "Is public Investment productive? 》 Journal of Monetary Economics, Vol. 23, pp. 177-200.

Ballard, C. L., D. Fullerton, J. B. Shoven, and J. Whalley (1985), A General Equilibrium Model for Tax Policy Evaluation, The University of Chicago Press.

Barro R. J. (1991), " Economic Growth in a Cross Section of Countries », Quarterly Journal of Economics, Vol 106, n², pp. 407-443.

Bergman, E.M. and Suan D. (1996), "Infrastructure and manufacturing productivity: Regional accessibility and development level effects", in D.F. Batten \& C. Karlsson, Infrastructure and the Complexity of Economic development (pp. 17-35), Heidelberg: Springer-Verlag Berlin.

Binder, S. A. and Smith, S. S.,(1997), Politics or principle?: filibustering in the United States Senate, Brookings Institution, Washington D.C., 248p. 
Blonigen, B. A., J. E. Flynn, and K. A Reinert (1997), Sector Focused general equilibrium Modeling, in (eds.) Francois, J.F. and K. A. Reinert, Applied Methods for Trade Policy Analysis, A Handbook, Cambridge University Press.

Boccanfuso, D. A. Estache and L. Savard, (2009) Impact Analysis of Electricity reforms in Senegal: A macro-micro analysis, Journal of Development Studies. Vol. 45, no 3 pp. $351-375$

Boccanfuso, D, M. Joanis, P. Richard, L. Savard, and B. Savy (2012). An estimation of the contribution of public capital for private sector growth, mimeo, GREDI, Departement of Economics, Sherbrooke University.

Commission de la construction du Québec, «Perspectives 2009: les projets publics soutiendront la construction», décembre 2008, http://www.ccq.org/Nouvelles/2008/1201Perspectives2009.aspx?sc_lang=frCA\&profil=Medias .

Decaluwé B., Martens A. and L. Savard (2001), " La politique économique du développement et les modèles d'équilibre général calculable ", Les Presses de l'Université de Montréal, Montreal, 509 pages.

Decaluwé, B., Lemelin A., and Bahan D. (2010) « Endogenous labor supply with several occupational categories in a bi-regional CGE Model ». Regional Studies, 44(10) pp. 1401 $-1414$.

de Melo, J. and D. Tarr (1992), A General Equilibrium Analysis of US Foreign Trade Policy, The MIT Press, Cambridge, Mass.

Dessus, S., and R. Herrera. 1996. "Le rôle du Capital Public dans la Croissance des Pays en Développement au cours des Années 80.” OECD Working Paper 115. Organisation for Economic Co-operation and Development, Paris.

Dumont J.C. et S. Mesplé-Somps (2000), « L'impact des infrastructures publiques sur la compétitivité et la croissance : Une analyse en EGC appliquée au Sénégal », Centre de recherche en économie du développement, Document de travail, ${ }^{\circ}$ 2000-08.

Estache A., Perreault J.-F. and L. Savard, (2010). "The impact of infrastructure spending in Sub-Saharan Africa: a CGE modeling approach," Policy Research Working Paper Series 5386, The World Bank

Gagnon M., Gaudreault V. and D. Overton (2008), « L'âge de infrastructure publique : une perspective provinciale », Statistique Canada, Document analytique, nº 2008-067.

Gramlich, E. 1994. "Infrastructure Investment: A Review Essay.” Journal of Economic Literature 32(3), pp.1176-1196. 
Gupta, S., R. Powell and Y. Yang (2006), The Macroeconomic Challenges of Scaling Up Aid to Africa: a Checklist for Practitioners, Washington DC, International Monetary Fund.

Hakfoort, J. (1996). "Public Capital, Private Sector Productivity and Economic Growt: A Macroeconomic Perspective”. pp. 61-72. In Batten, D.F. \& C. Kalsson (eds.). Infrastructure and the Complexity of Economic Development. Advances in Spatial Science. Springer. Berlin.

Harchaoui T.M. and F. Tarkhani (2003), " Le capital public et sa contribution à la productivité sur secteur des entreprises du Canada », Statistique Canada, Document de recherche, $\mathrm{n}^{\mathrm{o}}$ 11F0027MIF.

Levy S. (2007), " Public Investment to Reverse Dutch Disease Effect: The Case of Tchad», Journal of African Economies, Vol. 16, n 3, pp 439-484.

Ministère des Finances du Québec (2009), «Énoncé économique - Document explicatif Janvier 2009 », Gouvernement du Québec, 60 pages.

Munnell A.H. (1992), « Policy Watch: Infrastructure Investment and Economic Growth», The Journal of Economic Perspectives, Vol. 6, n ${ }^{\circ}$, pp. 189-198.

Savard, L. (2010) Scaling up Infrastructure Spending in the Philippines : A top-down bottom up micro-simulation approach, International Journal of Microsimulation. Vol. 3, no. 1, pp. 43-59.

Savard L. and E. Adjovi (1998), « Externalités de la santé et de l'éducation et bien-être : Un MEGC appliqué au Bénin. », l'Actualité Économique, Vol. 74, nº 3, pp. 523-560.

Secrétariat du Conseil du Trésor-SCT (2007), « Des fondations pour réussir : Plan québécois des infrastructures », Gouvernement du Québec, 15 pages.

Varian H.R. (1998), " Introduction à la microéconomie », traduction de la $4^{\mathrm{e}}$ édition américaine, De Boeck Université, 508 pages.

Yeaple S.R. and S.S. Golub (2007). "International Productivity Differences, Infrastructure, and Comparative Advantage", Review of International Economics, 15(2), pp. 223-242. 